\title{
Success Factors for Effective Contractor-led Stakeholder Relationship Management: Perspectives from the Botswana Construction Industry
}

\author{
Marian Taimu ${ }^{1 *}$, Bankole A wuzie ${ }^{2}$, and Alfred $\mathrm{Ngowi}^{2}$ \\ ${ }^{1}$ School of Business, Plot 50661, Fairgrounds, Gaborone, Botswana \\ ${ }^{2}$ Central University of Technology, Private Bag X 20539, Bloemfontein 9300, South A frica
}

\begin{abstract}
Stakeholder relationship management (SRM) remains critical to the attainment of successful project outcomes. This is particularly the case in the construction industry: an industry often described as considerably fragmented and project-based with a multiplicity of stakeholders with vested interests. Burgeoning incidences of project failure has been attributed to poor SRM. A lot of studies investigating stakeholder management exist, yet a paucity of studies looking into SRM has been noticed. M ost of these studies have sought to investigate the phenomenon from a client perspective without taking cognizance of the contractor's role in SRM. Also, the tendency of these studies to overlook stakeholder dynamics as it concerns power, uncertainty, etc. during various stages of the project lifecycle is observed. These are the gaps which this study will seek to fill relying on the customer relationship model (CRM) theoretical lens. A multicase study research design is proposed. Different contractor organizations were selected based on a set of predetermined criteria. A plethora of withincase interviews and document reviews will be utilized in eliciting data concerning the approach adopted by construction contractors for managing extant relationships with critical stakeholders. The data was analysed thematically. It is expected that success factors will result from the elicited narratives. The following success factors for effective management of stakeholder relationship management emerged from the interviews and documents: Communication, understanding of stakeholders, the different types of stakeholders and type of project, management, and interpersonal skills, collaboration, engagement, and conflict management. This artefact will be compared to different CRM models to identify probable success factors for engendering effective stakeholder relationship management. Furthermore, the study's findings will seek to contribute towards the development of a contractor-centric stakeholder relationship management framework for the B otswana construction industry.
\end{abstract}

Keywords: B otswana, Case studies, Construction, Customer Relationship $M$ anagement, Stakeholder

*Corresponding author: mataimu@gmail.com 


\section{Introduction}

Globally, construction industry clients have continued to grapple with increasing rates of dissatisfaction with project delivery outputs. The burgeoning rates of dissatisfaction have continued despite several interventions of industry stakeholders at different intervals and across geographical contexts. The largely fragmented and task-oriented nature of the industry, the fixation of inherent management techniques on the project delivery process instead of the functionality and utility of the project to the client as well as the opportunistic behaviour exhibited by project stakeholders have served, singularly or as a combination, to undermine the aspirations of industry clients, hence the dissatisfaction experienced. The scenario painted above is not peculiar to the developed world context but its predominance in the developing world context is troubling. This is particularly the case as countries in the latter require and are constantly commissioning new projects to meet their commitments to their citizenry in terms of improved welfare, productivity levels as well as national competitiveness. This aspiration has led to increased national borrowing and indebtedness, hence the need to ensure that projects deliver on their outline/original business cases. The debate on project management success and project success are yet inconclusive as both aspects are critical to engendering client satisfaction. Botswana happens to be one of such countries, classified as developing and in dire need for significant investments in infrastructure. As such, the onus falls on the local construction industry to provide the formwork for achieving this objective through efficient delivery of infrastructure and other ancillary services. The criticality of the industry to this venture cannot be overemphasized.

However, available evidence indicates that the Botswana construction industry has been unable to provide this support in a manner that is congruent with increasing levels of client satisfaction. Also, this shortcoming has negated the growth of the construction industry as clients are increasingly wary of inaugurating new projects, culminating in low receipts for the industry and indirectly impeding economic growth. In as much as certain studies have aligned themselves with previous studies which blame the nature of the construction industry and attitude of the stakeholders, particularly the client and the contractor, as constituting a hindrance to effective project delivery in Botswana, others have blamed the lack of skills and finance as failure factors bedevilling the industry. Furthermore, other studies have identified poor stakeholder management models or approaches applied by project teams as a salient failure factor [1-10].

Also, contracting organizations have been at the receiving end for the heightening levels of client dissatisfaction observed in the industry. This much is buttressed in a study by BIDP [11] wherein it was stated that: "Delays are common to construction projects in Botswana and contractors have often been unfairly singled out as the main culprits even when the delay was of a much more complex problem involving several stakeholders". This implies that contractors and contracting organizations in construction have a salient role to play in engendering improved project delivery via effective management of relationships with stakeholders. It must be acknowledged that whilst all the points raised in the literature remain valid, the extant literature on the management of stakeholders appears to be fixated on a static and dogmatic approach to stakeholder relationship management. A cursory look at the industry and the plethora of contractual arrangements governing the relationships reveal the sub-optimal nature of such static and dogmatic approaches for obvious reasons. However, a paucity of studies seeking, both to challenge the inadequacy of extant models and explore nascent ways of managing stakeholder relationships by contracting organizations in the Botswana construction industry and elsewhere has been noticed. This observation makes this study imperative. 
The construction industry is renowned for adopting processes for continuous improvement from other industrial sectors. Such innovative steps have culminated in new taxonomies like lean construction, servitization, etc. Taking a cue from such precursors, this study attempts to explore the utility of the extant customer relationship model (CRM) in bridging the gaps observed in the extant stakeholder management models. To do this effectively, this study will seek to explore the difference between stakeholder relationships and customer relationships and the management thereof. In furtherance to this, it is expected that elicitation of the success factors for optimal stakeholder relationship management by contractors will ensue following from a review of both approaches and the nature of construction project stakeholders. The problem statement of the study is to find the success factors for effective stakeholder relationship management in the context of Botswana's construction industry. The research question is what are the success factors for the effective management of stakeholder relationships for contractor firms in the Botswana construction industry? Based on the foregoing and seeming inability of the extant SRM models to cater effectively for the dynamics experienced by the contractors in the management of stakeholder relationships in construction projects, this study seeks to explore the utility of CRM models in catering to this gap.

\section{Literature Review}

\subsection{Concept of Customer Relationship management}

Oluseye [12] refers to the term relationship management as the process of managing the relationships between a firm and its internal and external publics. Since the inception of Customer Relationship Management (CRM) in the early 1990s, many attempts have been made to succinctly define the concept. One of the most comprehensive definitions cited by Buttle [13] is that ' $\mathrm{CRM}$ is an integrated approach to identifying, acquiring and retaining customers. Further to that Buttle [13] also defines CRM as the core business strategy that incorporates internal processes and functions, and external networks, to create and deliver value to targeted customers at a profit. Berndt and Tait [14] argue that the customer is jointly involved in adding value, thus more creative ideas are produced, and deeper relationships are built with them. Working with the customer and building relation through the project life cycle is an important aspect of project success.

\subsubsection{CRM in the Construction Industry}

Customer relationship management (CRM) is the all-inclusive process of building and maintaining profitable customer relationships in delivering superior value and satisfaction, dealing with acquiring, keeping and increasing consumers. Berndt and Tait [14] argue that the customer is jointly involved in adding value, thus more creative ideas are produced, and deeper relationships are built with them. CRM is a powerful concept to align the interests of a company and its customers [15]. CRM in the construction is mostly applied in the western world in comparison to Africa, Botswana. Stakeholder Relationship management in the construction industry is a relatively new phenomenon.

\subsubsection{Construction Industry and Customer Relationship Management in Botswana}

The construction industry in Botswana has had phenomenal growth, particularly in the last two decades. However, it has also experienced some problems and still faces numerous challenges, among them, human resource development, capacity development, and lack 
of competitiveness for citizen firms. According to Keaketswe [16], the construction industry has provided infrastructural support for the economy. Ssegawa-Kaggwa et al. [17] grouped the players in the construction industry into four categories mainly suppliers, regulators, clients, and facilitators.

\subsubsection{CRM Models}

There are numerous CRM models in existence CRM and these include Gartner's CRM Performance Scorecard [18], Forrester CRM Model [19], Conceptual Model (from [20]); The Strategic Model for CRM [21], The CRM Value Chain [13], the QCI Customer Management Model [22]. For this study, only three models will be discussed below.

The table below summaries a number of models that are found in customer relationship management. This IDIC model offers a simple way of relating with customers and it may be useful in construction, this is so because in construction there is always customisation of the end product to the customer's needs. The model identifies four actions that are needed to have a good relationship with the customer which are to identify the customer, differentiating the customer first by value and then secondly by need, interaction with the customer according to their needs and values and lastly to customise the final product to the specification of the customers' requirements. Strategy, Process, Technology, and People are the four types of groups by the Forrester CRM Model. The model is useful for kick-starting CRM programs for an organization that want to launch a CRM program [19]. This model will be able to help firms that find challenges in implementing the CRM. The Gartner's CRM Maturity model enables the firm to know where they are at the present and where they want to be over a period of time, what the requirement they will need to achieve that status of where they want to be [18].

\subsection{Customer Relationship Models}

Table 1. Summary of CRM models

\begin{tabular}{|l|l|l|l|}
\hline \multicolumn{1}{|c|}{ CRM Models } & \multicolumn{1}{|c|}{ Scholars } & \multicolumn{1}{c|}{$\begin{array}{c}\text { Relationship } \\
\text { Management }\end{array}$} & $\begin{array}{c}\text { Contractors use of } \\
\text { model (Analysis) }\end{array}$ \\
\hline CRM Value Chain & Buttle [13] & A nalysis of customer & $\begin{array}{l}\text { Contractor to provide } \\
\text { supporting conditions }\end{array}$ \\
\hline The QCI CRM & Hewson [22] & $\begin{array}{l}\text { V ariety of activities to } \\
\text { acquire and retain } \\
\text { customers }\end{array}$ & $\begin{array}{l}\text { Contractors need of } \\
\text { technology to manage } \\
\text { relations }\end{array}$ \\
\hline $\begin{array}{l}\text { Gartner's Crm } \\
\text { Performance } \\
\text { Scoreboard }\end{array}$ & IDM [18] & $\begin{array}{l}\text { Consideration of strategy, } \\
\text { processes, technology and } \\
\text { people }\end{array}$ & $\begin{array}{l}\text { Help contractors that } \\
\text { find it challenging to } \\
\text { implement CRM }\end{array}$ \\
\hline IDIC M odel & Pepper and Rodgers & $\begin{array}{l}\text { Identify, Differentiate } \\
\text { Interaction and Customize } \\
\text { customer requirements }\end{array}$ & $\begin{array}{l}\text { Contractors to } \\
\text { customize the product } \\
\text { to the customers } \odot \\
\text { specifications. }\end{array}$ \\
\hline $\begin{array}{l}\text { The Strategic } \\
\text { M odel for Crm }\end{array}$ & Payne [21] & $\begin{array}{l}\text { 5 stages used to manage } \\
\text { relations, Strategy process, } \\
\text { Value creation, } \\
\text { M ultichannel integration, } \\
\text { Performance assessment } \\
\text { and information } \\
\text { management }\end{array}$ & $\begin{array}{l}\text { Contractors may tally } \\
\text { the five stages with } \\
\text { the project life cycle } \\
\text { from inception to end } \\
\text { user in order to } \\
\text { manage relations }\end{array}$ \\
\hline Conceptual M odel & Desai [20] & $\begin{array}{l}\text { Linking the relationship } \\
\text { between dynamic }\end{array}$ & $\begin{array}{l}\text { Contractors may be } \\
\text { able to try the direct }\end{array}$ \\
\hline
\end{tabular}




\begin{tabular}{|l|l|l|l|}
\hline & & $\begin{array}{l}\text { capability for CRM and } \\
\text { competitive CRM } \\
\text { performance }\end{array}$ & $\begin{array}{l}\text { competences of the IT } \\
\text { variables see if they } \\
\text { make a change to } \\
\text { CRM }\end{array}$ \\
\hline $\begin{array}{l}\text { Forrester Crm } \\
\text { M odel }\end{array}$ & Forrester [19] & $\begin{array}{l}\text { 4 classes to manage } \\
\text { relations, Strategy, } \\
\text { Process, Technology and } \\
\text { People }\end{array}$ & $\begin{array}{l}\text { Helps contractors that } \\
\text { find challenges in } \\
\text { implementing the } \\
\text { CRM }\end{array}$ \\
\hline
\end{tabular}

\subsection{Understanding the Dichotomy between Stakeholder and Customers}

Construction project stakeholders would normally comprise of owners and users of facilities, project managers, employees, suppliers, visitors, suppliers, shareholder, subcontractors, banks, insurance companies, competitors, process and service providers, media, pressure groups, civic institutions, regional development agencies, the press, the natural environment, general public, community representatives, etc. Magliolo [24] eliminates the confusion between stakeholders and customers for projects as the customers have also been referred to as stakeholders. A customer can be described as any party that would be affected by a new product, including the main customers in the execution of the projects. Also, they may have both positive and negative implications on the project [24]. For this study, the customers include the above-mentioned stakeholders. The study will seek to view stakeholders like customers and the shareholders in the contracting firms. Relationships with the customer/s is key aspect in the business world and more so for the construction industry where there are projects with life cycles and different stakeholders at each stage. Future developments of the stakeholder theory should acknowledge that there is a lack of models to manage stakeholder relationships more efficiently [1]. Thus, the basis of this study will be underpinned by Customer Relationship Management (CRM) theoretical lenses as various models in CRM may be able to provide probable success. There is a range of definitions for CRM however for purposes of this study the following shall suffice, "CRM is a dynamic process of managing customers company relationships such that customers elect to continue mutually beneficial commercial exchange and are dissuade from participating in exchange that is not profitable".

\subsection{Significance of Stakeholders}

Weiss [25] defines a stake from stakeholder as a share or interest and the stakeholder being the individual with the stake. A contracting firm has many stakeholders who affect its operations and these contractors are in turn affected by the project. These consist of those which provide inputs (such as suppliers, society, financiers); regulatory bodies such the government; the community; owners (concerned with profits and survival of the firm or project); facilitators (e.g. employees, lawyers and financial advisers) and the customer who is the receiver of the final project. All these stakeholders need to have their concerns taken into consideration to avoid conflict that may hinder the progression and success of the project.

\subsection{Stakeholder Relationship Management}

Considering stakeholder management in the construction industry, the question of "Why does a project manager adopt a stakeholder management approach?" should be answered in advance [26]. Stakeholders being people the project manager will work with, must have their strategic and management processes to achieve success in the project. This may be achieved by managing relations with the stakeholders aiming for progression and success 
within the project. A construction project comprises of a series of complex activities. Bourne [2] observed that the project's success or failure was strongly influenced by both the expectations and perceptions of its stakeholders, and the capability and willingness of project managers to manage organizational politics. From previous studies, it can be found that stakeholder management is important in managing construction projects, and the reasons of managing stakeholders in construction projects include: Firstly, that the construction projects are complicated with many process and parties involved and secondly the relationships among stakeholders in construction projects are temporary [26]. Considering that the construction project is temporary and unique, relations with stakeholders need to be managed effectively to avoid conflicts that will lead to failure or abandonment of the project. Stakeholders are critical for a project's success thus it is of paramount importance to monitor them as they change positions during the life cycle of the project's progression [27].

Bourne [28] admits the importance of the processes supporting effective communication to the mission of building and maintaining healthy relationships with organizational stakeholders, through analysis of a case study - that of the construction and opening of Heathrow Terminal 5. The Heathrow T5 project was deemed to be one of the most successful projects because of innovative project management practices that focused on collaboration, cost $£ 4.3 \mathrm{bn}$.

Bourne [28] argues that for effective stakeholder relationship management the organization must be ready to absorb the new processes and practices further to that it must be fully developed, sensible and reliable and this defines maturity.

Six attributes have been identified as critical to the development of that a stakeholder relationship management model. They include: Standard Process, Centralized support Improvements in stakeholder relationship management a part of Key Performance Indicators, Organization-wide implementation, Developing Baseline and Proactive reporting on stakeholder relationship [28].

These attributes are used to determine the SRRM level form 1 to 5 with level 5 being the highest level. Level 5 shows that the organization can achieve all the five attributes within their projects.

\section{Research Method}

The study adopted a qualitative approach to investigates the phenomenon outlined previously. The case study strategy was deployed to develop an in-depth understanding of the phenomenon [29]. Three case studies where conveniently sampled from the building and construction works contractors. A total of 7 within the case- interviews were conducted. Relevant documents used by the contractors were availed for purposes of the report.

\subsection{Background of Case Studies}

Three privately owned contracting companies in the building category in Gaborone, Botswana were purposively selected. The cases were chosen based on their willingness to participate in the study. Convenience sampling was used. The cases were predetermined and selected on the basis of small, medium and large contracting firms based on grade. Case 1 is a small contracting firm, Case 2 a medium contracting firm and Case 3 a large contracting firm by grade. Recruitment calls were made to different contracting firms whose numbers were available on the integrated procurement management system-IPMS online Public Procurement and Asset Disposal Board (PPADB) website. The PPADB has the obligation to register contractors intending to bid for Central Government's procurement and asset 
disposal in respect of these three disciplines, works, supplies and services [30]. With the participant's consent, interviews were scheduled. Table 1: below summaries the characteristics of the three cases. Case numbers are used to protect the identity of the participating contracting firms and interviewees due to confidentiality reasons.

Table 2. Summary of the case study characteristics

\begin{tabular}{|l|l|l|l|l|}
\hline Case & Grade & Projects & Position & Code \\
\hline 1 & A & 1 & O wner & PM 1A \\
\hline 1 & & & A ssistant Project M anager & PM 1B \\
\hline 2 & C & 2 & Contractor M anager & PM 2A \\
\hline 2 & & & Project M anager & PM 2B \\
\hline 3 & E & 6 & Project M anager & PM 3A \\
\hline 3 & & & Project M anager & PM 3B \\
\hline 3 & & & Construction Site M anager & PM 3C \\
\hline
\end{tabular}

There are 10 types of ownership in contracting firms in Botswana ranging from $100 \%$ citizenship to $100 \%$ foreign, joint ventures and other types of ownership fall in between the two. Emphases are on empowering citizens in the construction industry. The contractor grades start from OC being the lowest grade A, B, C, D and E with E being the highest grade in accordance with their financial capability to fulfil the demands of the project.

Although the cases had contracts with different disciplines, the study focused on the Building and maintenance code underworks. Thou filed documents from previous projects were used, Case 12 and 3 had 1,2, and 6 projects respectively taking place at the time of the research.

\subsection{Data Collection}

Seven interviews of the Project Managers or similar position which had a role in managing the different stakeholders in their relevant projects within the contracting firm. A variety of semi-structured questions and in some cases unstructured were asked. Being a study that may be relatively new in the Botswana context a convenience sampling was used. These respondents were all permanent employees in the sampled constructing firms. Interviews were done in three months at the convenience of the participant.

During the interviews, notes were taken by the researcher and also recoding of the interviews was done through a voice recorder. Documents that were availed were those that were not confidential such as tender documents of past tenders and files for previous projects completed.

\subsection{Data Analysis}

Data were analyzed thematically relying on guidelines from Braun and Clarke [31]. The data from the three contractor cases were transcribed and to check for "accuracy" the researcher listened to the recordings on the voice recorder. The notes from the interviews and the documents from the contractors were read and re-read to obtain an appropriate level of detail for the study. The data that was generated from the transcription phase led to the coding phase which was comprehensive and thorough. The codes showed data that was relevant to the research question. There were repeated patterns of checking with the original data and the themes that were emerging. Thematic maps helped the research to draw themes from the codes, the maps helped to see links and visualize relationships between the themes [31]. 
The next stage of analysis of the data was interpreted and provided an organized story about the data and topic.

\section{Discussion of Findings}

\subsection{Presentation of findings}

The following success factors for effective management of stakeholder relationship management emerged from the interviews and documents: Communication, Understanding of changing dynamics of stakeholders, the stakeholders, and type of project, management skills, collaboration, engagement, and conflict management.

Table 3. Narration of respondents

\begin{tabular}{|c|c|c|c|}
\hline Theme & Case & Quotes & $\begin{array}{l}\text { Interviewee } \\
\text { Source }\end{array}$ \\
\hline Communication & 1 & $\begin{array}{l}\text { Communication is very important, ........customer } \\
\text { wants to save time and costs" }\end{array}$ & PM 1A \\
\hline $\begin{array}{l}\text { Understanding of } \\
\text { the changing } \\
\text { dynamics of } \\
\text { stakeholders }\end{array}$ & 2 & $\begin{array}{l}\text { The general public, clients, .......... general } \\
\text { stakeholders, and we have a generally positive } \\
\text { relationship with them but at times things do get out } \\
\text { of shape during the project. }\end{array}$ & PM 2B \\
\hline $\begin{array}{l}\text { Identification of } \\
\text { stakeholder/type } \\
\text { of project }\end{array}$ & 1 & $\begin{array}{l}\text { "The government projects are currently the best type } \\
\text {........ the private clients usually present problems } \\
\text { when it comes to payment." }\end{array}$ & PM 1B \\
\hline Collaboration & 3 & $\begin{array}{l}\text { Sometimes we take a long time asking for drawings } \\
\text { from government departments". }\end{array}$ & PM 3B \\
\hline $\begin{array}{l}\text { M anagement } \\
\text { support }\end{array}$ & 2 & $\begin{array}{l}\text { "We do not have any theoretical model that we } \\
\text { follow". }\end{array}$ & PM 2A \\
\hline $\begin{array}{l}\text { Interpersonal } \\
\text { Skills }\end{array}$ & 3 & $\begin{array}{l}\text { "We have a special position .... who takes care of all } \\
\text { documentation, we always have meetings with our } \\
\text { customers and final decisions are done by } \\
\text { management". }\end{array}$ & PM 3A \\
\hline Engagement & 3 & $\begin{array}{l}\text { "We always hold a meeting for us to maintain good } \\
\text { practices when it comes to stakeholder management, } \\
\text { they become committed and work with us". }\end{array}$ & PM 3C \\
\hline $\begin{array}{l}\text { Conflict } \\
\text { M anagement }\end{array}$ & 1 & $\begin{array}{l}\text { "When we are building for private clients, it is always } \\
\text { best we avoid building for family and friends." }\end{array}$ & PM 1A \\
\hline $\begin{array}{l}\text { Supporting } \\
\text { environment }\end{array}$ & 3 & $\begin{array}{l}\text { "The industry has a long way to go, it has great } \\
\text { potential. There is a need for more support from } \\
\text { government departments". }\end{array}$ & PM 3B \\
\hline
\end{tabular}

The table above gives a narration of the respondents from the interviews conducted. Bourne [28] defines communication as the primary tool for stakeholder relationships. Factors that can influence the effectiveness of communication and can include the relationship between the sender and the receiver, personal preferences, and cultural differences. Communication came out as one of the themes that are key when building or maintaining relationships with stakeholders. This theme emerged in all the data provided by the participants. There was an emphasis to be on the same understanding of the various issues that come up in the project. Communication is important both internally and externally in the contracting firm. Internally for the processes and progression of the project with the contracting firm and externally to monitor the environment. The above quotes on the table support that it is important to have effective communication plans with the various stakeholders during the life cycle of the project. 


\subsection{Understanding the changing dynamics of stakeholders during the different stages of the project.}

Chinyio [27] states that for each project to avoid any negative effects, there is a need to monitor the stakeholders and their stakes and respond to their dynamism. Being able to identify all the possible stakeholders that are within the confinements of the project was found to be important. All the cases were supportive that it is at the beginning of the project that stakeholders should be prioritized for the project to succeed. Another highlight was the fact that stakeholder priority and responsibility changes at different stages of the project life cycle as their power, interest, and urgency differed across the progression of the projects [27].

\subsection{Identification of stakeholders and the type of project}

The type of project that the contractor will be working on, will involve a different community of stakeholders and will also call for a different strategy to manage the relations. Also, the procurement method affects the project whether it is designed and build or traditional there are different stakeholders involved and these should be identified as per project. In comparison to the IDIC model, this finding aligns with the steps of the model.

\subsection{Management Support and Interpersonal skills}

Involvement by management from a strategic level and all other employees in the firm. Having an alignment of the stakeholder's interests with the requirements for the project to succeed. With the guidance of management relations within the progress of the project can be checked consistently and monitored throughout the project. Thacker [32] within the context of construction projects who pointed out that "Stakeholders make or break a project, and often Project Managers do not spend the time to effectively manage the stakeholder relationship - to the project's disadvantage. To be successful, Project Managers need to learn how to leverage the stakeholder relationship and how to balance their competing needs". Even thou interviewees had no knowledge of CRM and SRM from a theoretical perspective, certain practices and showed that they had ways of managing relations from a practical point of view. When inquired they had any documented CRM or SRM strategies. Case 2 replied, "We do not have any theoretical model that we follow." Management can also keep a database of all the relations they had with different projects as a reference to improve bad relations or maintain good relations in the coming projects.

\subsection{Engagement}

Including all or representatives of the stakeholders that would have been identified as those that would possibly have an influence that may affect relations within the project. Engaging the stakeholders in hearing their viewpoints and making them see their contribution to the success of the project.

\subsection{Conflict management}

Conflicts are unavoidable in situations where there are different stakeholders with different interests or stakes that need to be met. If left unmanaged conflicts can harm the relations with various stakeholder and this consequently may affect the value of the firm. Gibson [33] supports this aspect by concluding that stakeholders have the power to be either a benefit or a threat to the organization. 


\subsection{Collaboration}

Karlsen et. al [34] assert that collaboration is the best alternative for the stakeholders who have a high potential to affect the project, these stakeholders need to be closely worked with and always kept satisfied. Working together in the industry with all stakeholders with a common goal of progression and project success. In some instances, the contractors have a difficult time with certain government departments, policies and legal frameworks that delay the progression of their projects thus damaging relations with affected stakeholders.

\subsection{Supporting environment for the industry}

There was a different perception of the industry in Botswana from the three cases, mainly possibly because they are all in different grades and see the industry from the lenses of the grade they are in. Having a baseline that supports the industry for the country as a whole was found to be key. With a supportive business environment and probably a construction body such as the Construction Industry Development Board (CIBD), the contractors may be able to effectively manage their stakeholders. Ssegawa-Kaggwa-Kaggwa [35] supports this theme by stating that one of the reasons behind Botswana's inadequate capacity is the ineffective structure and organization of the construction industry characterized by constraints such as unavailability, insufficient or inappropriate use of resources, functions, and institutions.

\section{Conclusions}

This paper had success factors that emerged from the themes of the three case studies in the construction industry of Botswana. This highlights that the industry is currently fragmented and there is a need for all affected stakeholders to participate in creating good relations for the success of the projects. Some of the factors are well-known in literature as having relevance to the management of stakeholder relationships such as communication. The firms all agreed that managing relations with stakeholders is important Case 1 and 2 did not have any framework that provides guidelines for effective management of stakeholders they just take each case as it comes. Usually, the front office is the one that is first to meet or communicate with the different stakeholders. Case 3 had a more formal structure that deals with stakeholder's relationships and has an assigned person. Awareness of any formal models for SRM and CRM models was limited to none in all cases. It is recommended that the Industry is made aware of such models and adopt those that are applicable for their specific projects. Further studies in different regions in Botswana on SRM in the construction industry is encouraged, it is expected that future research would show more knowledge and insight into this study.

\section{Reference}

1. R.E. Freeman, Strategic M anagement: A stakeholder Approach (Pittman Publishing Company, B oston, 1984)

2. L. Bourne, and D. H.T. Walker, Visualising and mapping stakeholder influence, $M$ anagement Decision, 43(5): 649-660 (2005)

3. T. Donaldson, and L.E. Preston, The stakeholder theory of the corporation: Concepts, evidence, and implications, The A cademy of M anagement Review 20(1), 65-91 (1995)

4. A.L. Friedman, and S. M iles, Developing Stakeholder Theory, J ournal of M anagement Studies 39: 1-21 (2002) 
5. R. Phillips, R., Stakeholder Theory and Organizational Ethics (Berrett-K oehler, San Francisco CA, 2003)

6. D.I. Cleland, Project Stakeholder Management, Project M anagement J ournal 17(4): 3644 (1986)

7. J. Y ang, Q.P. Shen, L. Bourne, M.F. Ho, and X.L. Xue, A typology of operational approaches for stakeholder analysis and engagement: findings from Hong Kong and Australia, Constr. M anag. Econ. 29(2): 145-162 (2011)

8. J. Frooman, Stakeholder influence strategies The Academy of Management Review 24(2): 191-205 (1999)

9. J. Nasi, Understanding Stakeholder Thinking (L SR-J ulkaisut Oy, Helsinki, 1995)

10. T.J. Rowley, Moving BEYOND Dyadic Ties: A Network of Stakeholder Influences, A cademy of M anagement Review 22(4): 887-910 (1997)

11. BIDP, Botswana Institute of Development Professionals, Delays, Disruptions and Suspensions in Construction contracts, http://bidp.bw/?q=node/13 (2015)

12. O.O. Oluseye, B.T. Tairat, and J.T. Emmanuel, Customer Relationship Management Approach and Student Satisfaction, Higher Education M arketing 6(3): 49-62 (2014)

13. F. Buttle, Customer relationship management: Concepts and technologies (Elsevier Butterworth-H einemann, Burlington M A, 2009)

14. A. Berndt, and M. Tait, Relationship Marketing and Customer Relationship $M$ anagement, $3^{\text {rd }}$ Edition (Juta A cademic, 2014)

15. W. Boulding, R. Staelin, M. Ehret, and W.J. Johnston, A Customer Relationship Management Roadmap: What is Known, Potential Pitfalls, and Where to Go, J ournal of M arketing 69(4): 155-166 (2005)

16. K. K eaketswe B otswana Press A gency,(BOPA) http://www.dailynews.gov.bw/mobile/news-details.php?nid=24042\& flag=5 (2015)

17. J. Ssegawa-Kaggwa, A.B. Ngowi, and K. Ntshwene, Using a Situation Analysis to Identify the Construction Industry Deficiencies in Botswana, Journal of Construction in Developing Countries 18(1):1-18 (2013)

18. IDM , Institute of Direct M arketing, The IDM Guide to CRM M astery (2002)

19. Forrester Research, Forrester's Best Practices Framework for CRM (2007)

20. D. Desai, S. Sahu, and P.K. Sinha, Role of dynamic capability and information technology in customer relationship management: A study of Indian companies, V ikalpa 32(4): 45-62 (207)

21. A. Payne, and P. Frow, Customer relationship management: from strategy to implementation, J ournal of M arketing M anagement 22(1-2): 135-168 (2006)

22. Hewson Group, CRM in the public sector, http://www.hewson.co.uk (2002)

23. D. Pepper, and M. Rodgers, M anaging Customer Relationships: A Strategic Framework (J on W iley \& Sons, Inc, , Hoboken NJ , 2004)

24. J.M . M agliolo, The guerilla principle - winning tacticts for Global Project M anagers, 1st Edition (Juta and Company, 2008)

25. J.W. W eiss, Business Ethics - A stakeholder and Issues Management A pproach, $4^{\text {th }}$ E dition ( $M$ ason Thomson Higher Education, 2006)

26. J. Y ang, Q. Shen, and M. Ho, An overview of previous studies in stakeholder management and its implications for the construction industry, Journal of Facilities M anagement 7(2): 159-175 (2009)

27. E.A. Chinyio, and P. Olomolaiye, Construction stakeholder management (WileyBlackwell, Oxford, England, 2010)

28. L. B ourne, Stakeholder R elationship M anagement: A M aturity M odel for Organisational Implementation (Routledge, 2009)

29. R.K. Y in, Case study research, Design and methods, 4th Edition (Sage, 2009) 
30. PPADB, Public Procurement Asset Development Board, http://www.ppadb.co.bw/ (2016)

31. V. B raun, and V. Clarke, Using thematic analysis in psychology, Qualitative Research in Psychology 3(2): 77-101 (2006)

32. A. Thacker, The relationship manager (CreateSpace Independent Publishing Platform, 2017)

33. K. Gibson, The moral basis of stakeholder theory, J ournal of B usiness Ethics 26(3) :245257 (2000)

34. .J.T Karlsen, K. Græe, and M.J. Massaoud, Building Trust in Project - Stakeholder Relationships, B altic M anagement J ournal 3(1):7-23 (2008)

35. J. Ssegawa-K aggwa, Construction industry's contribution towards Botswana's vision 2016, 15th A nnual A RCOM Conference, Liverpool, 15-17 September 1999 